\title{
集合住宅の音環境に対する居住者の生活実感と住まい方に関する研究 RESIDENT AWARENESS AND OCCUPANCY BEHAVIOR FOR SOUND ENVIRONMENT IN MULTI-FAMILY HOUSING
}

\author{
阿部今日子*, 井上勝 夫** \\ Kyoko ABE and Katsuo INOUE
}

\begin{abstract}
We did a questionnaire for residents in multi-family housing on resident awareness, supplier's explanation and occupancy behavior concerning sound environment. We obtained 784 valid response numbers of questionnaires votes. We analyzed the questionnaire survey from various angles, As a result, we obtained the following conclusion.

(1) The dissatisfaction of "floor impact sound insulation performance using heavy impact source" in sound environment is still high.

(2) The effect of a prior explanation by the housing supplier is not seen about the resident awareness of "Floor impact sound".

(3) It is accepted to the resident to receive the restriction to the way of living on multi-family housing as "Manners".
\end{abstract}

Keywords : Multi-family housing, Sound environment performance, Resident awareness, Occupancy behavior 集合住宅，音環境，居住者意識，住まい方

\section{1.はじめに}

わが国における住宅政策は、戦後の住宅建設計画法の下、住宅建 設五箇年計画の着実な実施を通じ「量の確保」を図ってきたが、2000 年に住宅の品質確保の促進等に関する法律が制定され「住宅性能表 示制度」がスタートし、2006 年に住生活基本法が施行、2007 年には 建築基準法が改正されるなど、法制度的にも「量の確保」から「質の 向上」へ本格的な転換を図る時期を迎えている。

それに伴い建築技術の向上を受け、居住後の満足度が向上してき ていると思われるが、国土交通省がまとめた「平成 15 年度マンショ ン総合調查結果」1)によると、約 9 割のマンションで何らかのトラブ ルが発生しており、その中でも「居住者のマナーをめぐるトラブル」 が最も多く、8 割を超えるマンションで発生しているという報告も ある。特に、生活音」に関するトラブルは半数を超える (52\%) 管理組 合で生じており、違法駐車・駐輪 $(55 \%)$ に次いで 2 番目に多く深刻 な問題となってる。生活音に関するトラブルは、近年のマンション ブームに加え、近所付き合いの低下 2 ) やライフスタイルの多様化な どを受け、トラブルの深刻さが増してきており、騒音トラブルの未 然防止・対策のための措置を講じることが社会的急務となってい る。

このような騒音トラブルの解決を望む社会的ニーズに応えていく
ためには、音環境制御技術の向上などハード面からのアプローチだ けでなく、現実的な解決方法を探る意味でも住まい方などのソフト 面による生活実感改善の可能性についても把握しておくことが重要 である。特に、住まい方のマナーやモラルに関する居住者意識を分 析し、生活上の共通ルールなどを具体的に提案していけるようにす る事が非常に重要であると考えられる。

居住者の住宅に対する意識調查については、国土交通省等からも 報告 ${ }^{3)}$ されているが、音環境を中心とした調査に関する報告は非常 に少ない。筆者らのグループは、これまで集合住宅の音環境に対す る居住者の生活実感に関する研究として、1980 年前後 ${ }^{4) 5)}$ と 1995 年 前後 ${ }^{6}$ ～9) の大きく 2 期に渡って調查研究を行い、社会的に貴重な データを提示してきているが、近年行われた同様の調査結果につい ては他機関なども含め報告例は極めて少ない。また、本研究の新規 性として、近年の法整備やアカウンタビリティへの関心の高まりな ぞ、社会的要求の変化を勘案して、既報 ${ }^{4)}$ ９）とは異なる新たなアプ ローチとして、居住者の意識調査のみに着目するのではなく、住宅 購入前の消費者要求や供給者の説明状況 ${ }^{10)}{ }^{11)}$ を含め系統的な研究を 展開している点が挙げられる。このようなアプローチによる研究 は、今後、騒音トラブルを低減させていく若しくは解決させる際

\footnotetext{
* 日本大学 大学院生 $\cdot$ 修士 (工学)

(日本 ERI (株)

** 日本大学理工学部建築学科 教授. 工博
} 
に、重要な判断資料となるものと考えている。

そこで、本報では、住宅性能や音環境性能に対するごく最近 ( 竣 工が 2000 年以降) 建設された集合住宅を対象として居住者意識を把 握すると共に、営業担当者等の販売時における音環境性能に関す る事前説明内容や消費者 ( 居住者) の説明要求内容、さらに住まい 方に対する意識や実態を明らかにし、集合住宅居住のマナーとし て求められる住まい方や、今後、建築性能 (遮音性能)をどの程度 まで向上させる必要があるのか等について検討した結果を報告す る。

\section{2. アンケート調査概要}

アンケート実施物件概要を表 1 に示す。調查対象物件は、建築着 工統計調查 (国土交通省) ${ }^{14}$ ) より 分譲マンションの着工新設住宅戸数 が首都圈 (東京、神奈川、埼玉、千葉)に約半数集中していること を参考とし、表 1 に示す 1 都 3 県 31 物件を調査対象として選定した。 なお、本調查対象は住宅性能表示制度がスタートした 2000 年以降 に竣工した物件を中心に選定しているが、参考として 1999 年以前 の物件についてもいくつか併せて調查を行っている。調査は 2003 年から 4 期にかけて行い、有効票は 784 票を得た。

代表的な質問項目を表 2 に示す。質問は、性能全般に関するこ と、音環境に関すること、住まい方・配慮に関することの大きく 3 部分に分かれている。質問項目は、各期ごとに前期の結果を踏ま えて必要なものを追加・変更している。

アンケートの調査方法は留め置き調查法を採用し、対象物件の 各管理組合から調查協力の承諾を得た後、調查書を各住戸のポス トに投函し、管理人室等で回収箱により回収する方法とした。

\section{3. アンケート調査結果}

\section{1 回答者の属性}

回答者の属性を表 3 に示す。男女の比率はほぼ $1: 1$ で、年齢分 布は 30 代が $32 \%$ ・40 代が $26 \%$ ・50 代が 19\%、職業は会社員が $46 \%$ 主 婦が $27 \%$ 、家族構成は核家族が $38 \%$ ・夫婦のみが $33 \%$ となっている。

\section{表 1 居住者アンケート実施物件概要}

\begin{tabular}{|c|c|c|c|c|c|c|}
\hline & 実施時期 & 所在地 & 竣工時期 & 2000年以降 & 総住戸数 & 有効票 \\
\hline \multirow{5}{*}{ 期 } & 2003年8月 & 東京都新宿区 & 2003.2 & 0 & 281 & 64 \\
\hline & 2003年9月 & 毛葉県市川市 & 1999.11 & $x$ & 108 & 39 \\
\hline & 2003年10月 & 東景都大田区 & 1981 & $\bar{x}$ & 27 & \\
\hline & 2003年11月 & 埼玉県さいたま市 & 1986 & $x$ & 97 & 37 \\
\hline & 2003年12月 & 埼玉県川口市 & 1985 & $x$ & 38 & \\
\hline \multirow{7}{*}{ 期 } & 2004年11月 & 東京都文京区 & 2003 & $\mathrm{O}$ & 35 & \\
\hline & 2004牢12月 & 東龺罪武蔵野市 & 2003.11 & 0 & 134 & 15 \\
\hline & 2004年12月 & 東京都西東京市 & 2003.8 & 0 & 381 & 31 \\
\hline & 2004年12月 & 東京都府中市 & 2003.2 & 0 & 145 & 19 \\
\hline & 2004年11月 & 神奈川県横浜市 & 2003.2 & 0 & 262 & 61 \\
\hline & 2004年12月 & 神奈川県横浜市 & 2003.3 & 0 & 157 & 13 \\
\hline & 2005年1月 & 菄京都江吉川区 & 1988 & $x$ & 311 & 113 \\
\hline \multirow{6}{*}{$\begin{array}{l}\text { III } \\
\text { 期 }\end{array}$} & 2005年10月 & 東京都中央区 & 2003.9 & 0 & 110 & 22 \\
\hline & 2005年11月 & 菄京都大田区 & 2004.2 & 0 & 104 & 13 \\
\hline & 2005年11月 & 千葉県千葉市 & 2004.7 & 0 & 224 & 67 \\
\hline & 2005年11月 & 菓景都大田区 & 2004.3 & 0 & 159 & 37 \\
\hline & 2005年11月 & 千葉県千禁市 & 2004.2 & 0 & 188 & 18 \\
\hline & 2005年12月 & 軍京都葛飾区 & 2004.3 & 0 & 157 & 18 \\
\hline \multirow{13}{*}{ 期 } & 2006年11月 & 東京都文京区 & 2003.2 & 0 & 106 & \\
\hline & 2006年12月 & 菄京都毛代田区 & 2004.9 & 0 & 319 & 27 \\
\hline & 2006年12月 & 神奈川県横浜市 & 2004.10 & 0 & 115 & 13 \\
\hline & 2006年12月 & 千妄県千案市 & 2006.1 & 0 & 228 & 49 \\
\hline & 2006年11月 & 菄京都文京区 & 2003.4 & 0 & 74 & \\
\hline & 2006年11月 & 稞京都台東区 & 2001 & 0 & 65 & \\
\hline & 2006年11月 & 菄京都台東区 & 2002.8 & 0 & 97 & 11 \\
\hline & 2006年12月 & 菄京都世田谷区 & 1998 & $x$ & 26 & 5 \\
\hline & 2006年12月 & 菓京都世田谷区 & 2002.3 & 0 & 57 & 4 \\
\hline & 2006年12月 & 東京都渋谷区 & 2002.3 & 0 & 116 & \\
\hline & 2006年12月 & 神奈川県横浜市 & 2006.1 & 0 & 78 & 16 \\
\hline & 2006年12月 & 字妄県船橋第 & 1998.2 & $x$ & 69 & 11 \\
\hline & 2007年3月 & 埼玉県川口市 & 2001.3 & 0 & 222 & 36 \\
\hline & & & & & 4490 & 78 \\
\hline
\end{tabular}

表 2 居住者アンケートの質問項目

\begin{tabular}{|c|c|c|}
\hline \multirow{6}{*}{\begin{tabular}{|l|} 
\\
性 \\
能 \\
全 \\
般
\end{tabular}} & & \begin{tabular}{|l} 
調查時期 \\
$\mathrm{I}|\mathbb{I}| \mathbb{I}|\mathrm{I}| \mathrm{V}$
\end{tabular} \\
\hline & 建物の総合的な性能の満足度。不満点。〈自由意見〉 & \\
\hline & 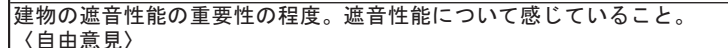 & \\
\hline & 住宅の選定条件。入居後の不満点・改善希望点。 & \\
\hline & 住宅性能10項目に対する選定時の考慮の度合い & \\
\hline & 住宅性能10項目に対する入居後の満足度 & \\
\hline & 音環境4項目に対する選定時の考慮の度合い & \\
\hline & 音環境4項目に対する入居後の満足度 & \\
\hline & 防音性能についてどのように感じるか。問題意識の程度。 & \\
\hline & 以前の住まいと比較して防音性能はどうか。 & o \\
\hline & 購入前の想像と比較して、居住後の防音性能はどうか。 & \\
\hline & 音環境は実際に住んでみないとわからない部分があることに & \\
\hline & 忍階や隣戸からの聞こえる程度、気になる程度、うるささの程度はどう & \\
\hline & 上階や隣戸の様子について気配を感じる程度はどうか。 & \\
\hline & 表示尺度と住宅における生活実感との対応の例で当てはまるものに丸を & \\
\hline & \begin{tabular}{|l|} 
つける。 \\
生活音だと思う音は。
\end{tabular} & \\
\hline & 聞こえる音、音の方向、室名、聞こえ方は。 & \\
\hline & 聞こえる音、気になる音。どのような対策が必要か & \\
\hline & $\begin{array}{l}\text { 上階からの音により、どのような時にどのような気分になりどのような } \\
\text { 行をとるか。 }\end{array}$ & \\
\hline & 購入前に営業担当者等から、音環境について説明されたか。 & \\
\hline & 具体的に説明された内容は何か。〈自由意見〉 & \\
\hline & $\begin{array}{l}\text { 現在の音環境を購入前にどのように説明して欲しかったか。 } \\
\text { 購入前の自分に説明するとしたら゙のように説明するか。〈自由意見〉 }\end{array}$ & \\
\hline & 営業担当者等が最低限説明するべき内容は何か。 & \\
\hline & $\begin{array}{l}\text { 床衝撃章についてどのような説明をしてもらいたかったか。 } \\
\text { 〈自由見〉 }\end{array}$ & \\
\hline & 購入する前に、音環境について自ら勉強したか。 & \\
\hline & 自分の出す音に配虜しているか。自分の足音に配慮しているか。 & \\
\hline & 発生音の防止・足音防止についてエ夫していることは。〈自由意見〉 & \\
\hline & 配虜するべき時間帯(隣戸・掃除機・洗濯機・楽器)〈自由意見〉 & \\
\hline & 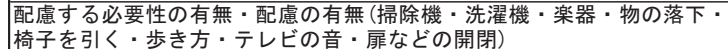 & \\
\hline & 自分や家族が出す音で配慮しているもの。〈自由意見〉 & \\
\hline & 一般的な意見として、集合住宅では他住戸の音環境を良好に保つために & \\
\hline & \begin{tabular}{|l} 
雔まいちの配慮が必要か。 \\
合住宅に住むにあたって、音環境を良好
\end{tabular} & \\
\hline & 住まい方はどの様なことか。〈自由意見〉 & \\
\hline & 騒音トラブル防止のためには何が必要か。 & \\
\hline 住 & あなた自身の住まい方が他住戸の音環境に対して迷惑をかけていると思 & \\
\hline & \begin{tabular}{|l} 
フか。 \\
具体的に迷惑をかけていることは。〈自由意見〉
\end{tabular} & \\
\hline 方 & 他住戸の音環境を良好に保つために、自分の住まい方が制限されること & \\
\hline & 今まで音に䍘して何が注意をした、又はされたことがあるか。その内容 & \\
\hline 酸 & は何か。〈自由意見〉 & \\
\hline & $\begin{array}{l}\text { 子供がマンショコン内へ立ち入る事、子供が近隣住戸・上階に住むことに } \\
\text { 抵抗があか。 }\end{array}$ & \\
\hline & 共用部・近隣住戸・上階の子供には住まい方に配慮して欲しいか。 & \\
\hline & 子供になるべく音を立てさせないようにさせる必要があると思うか。 & \\
\hline & $\begin{array}{l}\text { 配慮するる必要性の有無・配慮の有無 (走り回り・飛び跳ね・騒ぐ・おも } \\
\text { ちゃやボ落下) }\end{array}$ & \\
\hline & 子供が発生させる音について配虜していること(配慮して欲しいこと)。 & \\
\hline & 子供が室内で行っている遊びは。〈自由意見〉 & \\
\hline & 家の中と外のどちらで遊ぶことが多いか & \\
\hline & 近所の公園で子供を遊ばせることに抵抗がある & \\
\hline & $\begin{array}{l}\text { 子供が發生させている音に対して注意する頻度は。その効果はあるか。 } \\
\text { 効果があるとは何か。自由意見〉 }\end{array}$ & \\
\hline
\end{tabular}

表 3 居住者アンケート回答者の属性等

\begin{tabular}{|c|c|}
\hline 性別 & 男性 (51) 女性 (49) \\
\hline 年齢 & \begin{tabular}{|lrll}
20 代 (4) 30 代 (32) & 40 代 (26) & 50 代 (19) & 60 歳 64歳 (7) \\
65 歳以上 (12)
\end{tabular} \\
\hline 職業 & 会社員 (46) \\
\hline 家族構成 & 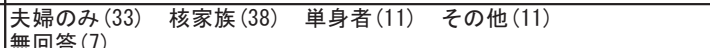 \\
\hline 所有形態 & \begin{tabular}{|lll} 
持ち家 (91) & 賃貸 (7) & その他 (1) \\
無回答 (1)
\end{tabular} \\
\hline 居住年数 & $\begin{array}{llll}\begin{array}{l}\text { 6ヶ月未満(12) } \\
\text { 10年以上 }\end{array} \text { (12) } & \text { 無回年 (46) } & \sim 5 \text { 年 (19) } & \sim 10 \text { 年 (8) } \\
\end{array}$ \\
\hline $\begin{array}{l}\text { 現在の住宅の } \\
\text { 購入価格 }\end{array}$ & 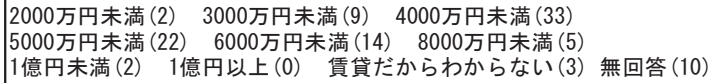 \\
\hline $\begin{array}{l}\text { 以前の住宅形 } \\
\text { 式 }\end{array}$ & 戸建 (27) 長屋 (1) 集合住宅 (70) その他 (1) 無回答 (1) \\
\hline \begin{tabular}{|l} 
以前の住宅の \\
所有形態
\end{tabular} & 持ち家 (44) 賃貸 (53) その他 (2) 無回答 (1) \\
\hline $\begin{array}{l}\text { 以前の住宅の } \\
\text { 構造 }\end{array}$ & 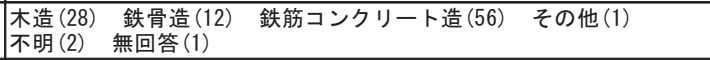 \\
\hline $\begin{array}{l}\text { マンション全 } \\
\text { 体の付き合い }\end{array}$ & 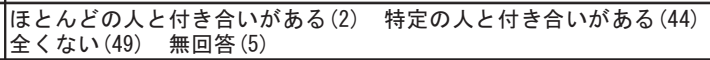 \\
\hline \begin{tabular}{|l|} 
上階住人との \\
付き合い
\end{tabular} & 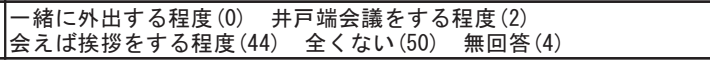 \\
\hline
\end{tabular}


住戸の所有形態は 9 割が持ち家で、居住年数は半年から 2 年末満が $46 \%$ 、住宅の購入価格は 3000 万円〜 5000 万円未満が半数を超えてい る。現住宅に居住する以前の住宅形態は 7 割が集合住宅で、所有形 態は賃貸が $53 \%$ ・持ち家が $44 \%$ となっている。

\section{2 住宅性能・音環境性能}

住宅選定時における住宅性能に対する考慮の度合いを図 1 に示す。 図中には、参考として竣工が 1999 年以前の物件についても併せて示 している。『防犯』については2005 年に住宅性能表示制度の評価項 目に「防犯に関すること」が追加されたのを受け、IV期のみの調查結 果を載せている。

「かなり考慮した」と「やや考慮した」の合計值をみると、1999 年以 前の物件では、『光・視環境』が 7 割を超えているが、他の性能項目 は 6 割以下と低い。しかし、竣工が 2000 年以降の物件では、全項目 ともほぼ 6 割以上を示している。特に、『構造』、『光・視環境』では 9 割以上、『防犯』、『音環境』では 8 割以上の人が考慮しており、非 常に関心が高い項目といえる。

次に居住後の満足度を図 2 に示す。 2000 年以降の物件に対する満 足度は全体的に高く、考慮度合いの高い消費者要求を近年の集合住 宅ではほぼ満足させていることがわかる。特に、『高齢者への配慮』 については、バリアフリーが標準となっている住宅が増えたことか ら満足度が高いものと思われる。しかし、音環境項目のみ満足度が 7 割以下と最も低くなっており、考慮しているにも関らず居住後の 満足度が低いのは、住宅選定時に性能を具体的に捉えにくいためと 推察される。

音環境性能を左右する代表的な 4 項目に対する考慮の度合いを図 3 に示す。 2000 年以降の物件では考慮した度合いが 8 割以上を示して おり、それぞれの部位性能に対する関心が高い事がわかる。図 4 の 居住後の音環境に対する満足度をみると、2000 年以降の物件では全 体的に満足度が高く、性能の向上が生活実感として認知されている と考えられるが、依然として『重量床衝撃音』と『空気伝搬音 (外壁 開口部）』に対する不満がみられる。

具体的に聞こえる音・気になる音に関する回答結果を図 5 に示す。 1999 年以前の物件では、「トイレ・浴室・台所の給排水音」の指摘が高 いが 2000 年以降の物件では大きく改善されており、給排水管の支持 方法や躯体貫通部の防振対策などの騒音低減技術の向上効果がみら れる。しかし、「子供の飛び跳ね・走り回る音」、上階からの足音」、物 の落下音」は依然として上位にあげられている。これらの音は既報 ${ }^{6)}$ で報告している「遮音性能が悪いと感じる音」でも上位に位置してい ることから、今後、更なる性能向上が求められているといえる。

次に、図 5 で聞こえる音・気になる音として上位にあげられたも ののうち 4 種類の音(「子供の飛び跳㸚・走り回る音」、上階からの足 音」、物の落下音」、椅子・家具の移動音」）について、具体的な対策 方法の検討を行なった。図 6 は、上階からの音に対して感じている 問題意識について、「全く問題ない」「ほとんど問題ない」を『問題な い』「普通」を『普通』、やや問題がある」問題がある」「かなり問題が ある」を『問題がある』として、問題意識の程度別にそれぞれの音に ついて望んでいる対策方法を集計した結果である。

上階からの音に対して『問題ない』と回答している人は、どの音 についても「対策の必要を特に感じない」が多い結果となっている。

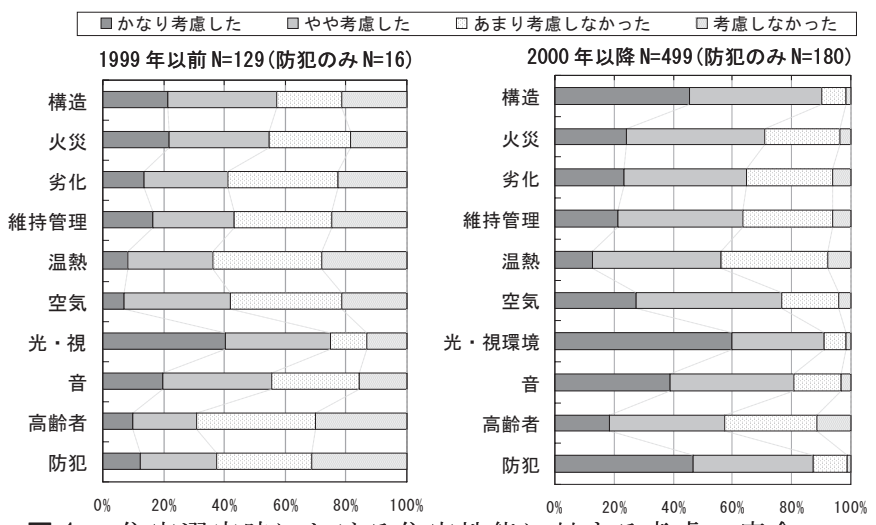

図 1 住宅選定時における住宅性能に対する考慮の度合い

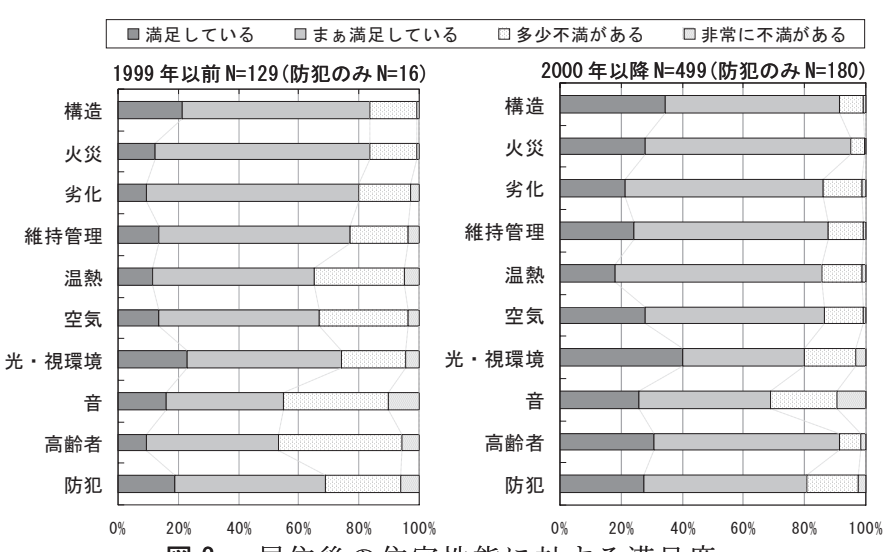
図 2 居住後の住宅性能に対する満足度

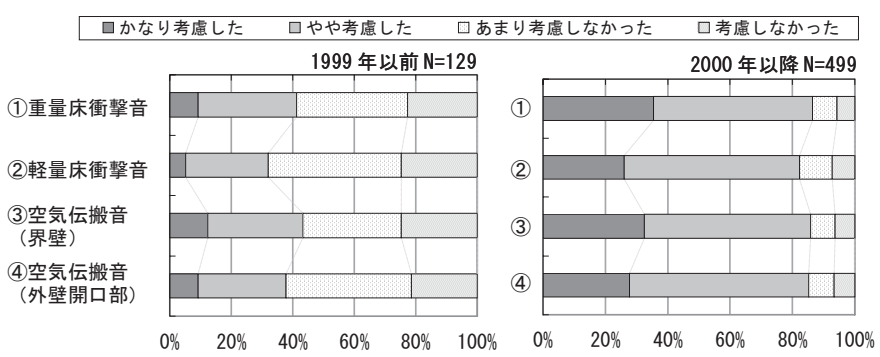

図 3 住宅選定時における音環境性能に対する考慮の度合い

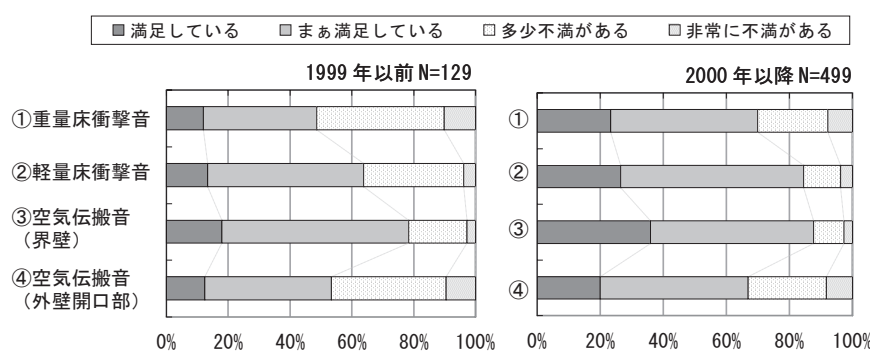

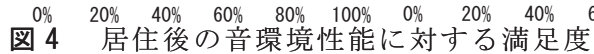

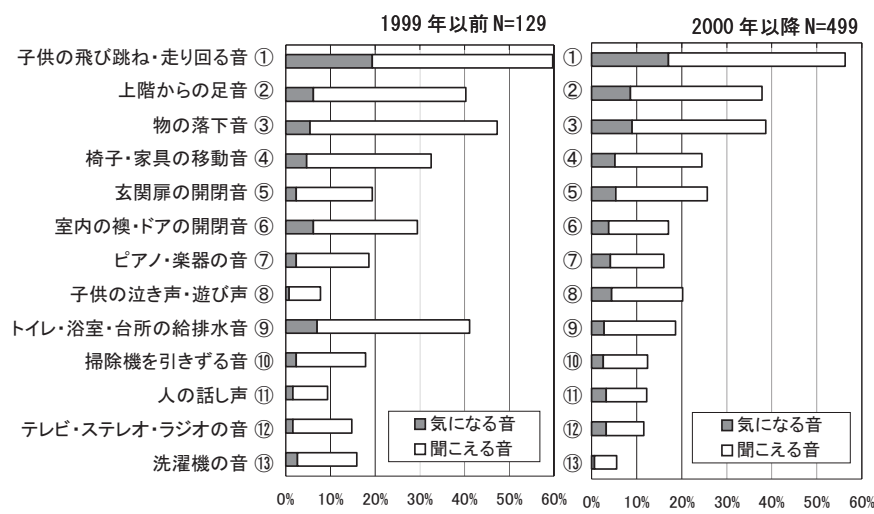

図 5 聞こえる音・気になる音 
『普通』と回答している人は、どの音でも「生活音だから仕方がない と思う」が多く、『普通』との回答は共同住宅であるが故の許容を入 れた判断であると推察される。しかし、『問題がある』と回答した 人は、「上階からの足音」に対しては、「居住者の住まい方等による改 善が必要」と「生活音だから仕方がないと思う」が同程度であるのに 対して、子供の飛び跳ね・走り回る音」については「居住者の住まい 方等による改善が必要」の指摘が 4 割と高くなっており、建物の遮 音性能もさることながら住まい方に問題意識を感じていることがわ かる。このことから、子供の飛び跳ねのような行動は、自ら慎む心゙ きこととする生活上のモラルが居住者間に創造されつつあることを 示唆するものである。よって、今後は住まい方とその効果について の詳細な検討も研究課題の 1 つであるといえる。

\section{3 購入前の事前説明内容と居住者の説明要求内容}

本項では、営業担当者等による購入前の事前説明内容や消費者 (居住者)の説明要求について報告するため、現在の所有形態が「持 ち家」の回答者のみの結果を検討対象とした。

事前説明の程度を図 7 に示す。『上階からの音』では、「特に説明 されなかった」と「パンフレットに記載されている内容などは説明さ れた」が同程度、『隣戸からの音』、『外からの音』では、「特に説明さ れなかった」が最も多く、どの音でも「居住後に発生する可能性があ る問題点なども説明された」割合は 1 割程度にとどまっている。

具体的に説明された内容 (表 4) をみると、的確な説明の一方で、 「問題ない」や「気にならない」という感覚的表現や建築仕様のみを説 明、また実現象を正確に捉えているとは言い難い曖昧な説明もみら れ、既報10１11) でも報告した供給者の説明不足又は説明内容・方法の 不適正さが本調查結果からも改めて示された。

次に、現在の音環境を購入前にどのように説明して欲しかった か質問した結果 $($ 表 5 ) をみると、説明に不満を感じていない人がい る一方で、具体的に聞こえてくる音の種類や程度、具体的な数值 $(\mathrm{dB})$ 、それぞれの地域の特色や建物の特徵などを踏まえた説明が求 められている。また、容易に実際の音を体験できるようなシステム も求められている。

さらに、具体的に営業担当者が最低限説明すべき内容について質 問した結果（図 8 ）をみると、「聞こえてくる可能性のある音の種類 と程度」などの具体的な要求に続き、「防音対策を行っている部位と その性能」などの性能に対する技術的・定量的要求が 5 割を超えて おり、今後、これらの消費者要求に応え得る適切な説明を行えるよ うに、既報10111)で報告した営業担当者の説明状況なども踏まえなが ら、現実的な提案をしていく必要がある。

ここで参考として、購入前の事前説明の程度別に居住後の満足度 を集計した結果を図 9 に示す。『隣戸からの音』と『外からの音』を みると、「特に説明されなかった」、「パンフレットに記載されている 内容などは説明された」、「居住後に発生する可能性がある問題点な ども説明された」と説明度合いが上がるほど入居後の満足度が上 がっており、購入前の事前説明の程度が居住後の満足度に影響を与 えていると考えられる。また、隣戸からの音に関しては「満足して いる」と「まあ満足している」をあわせると、説明がない場合でも 8 割以上を示しており、界壁の遮音性能については現状でかなり満足 のいくものであると推察される。

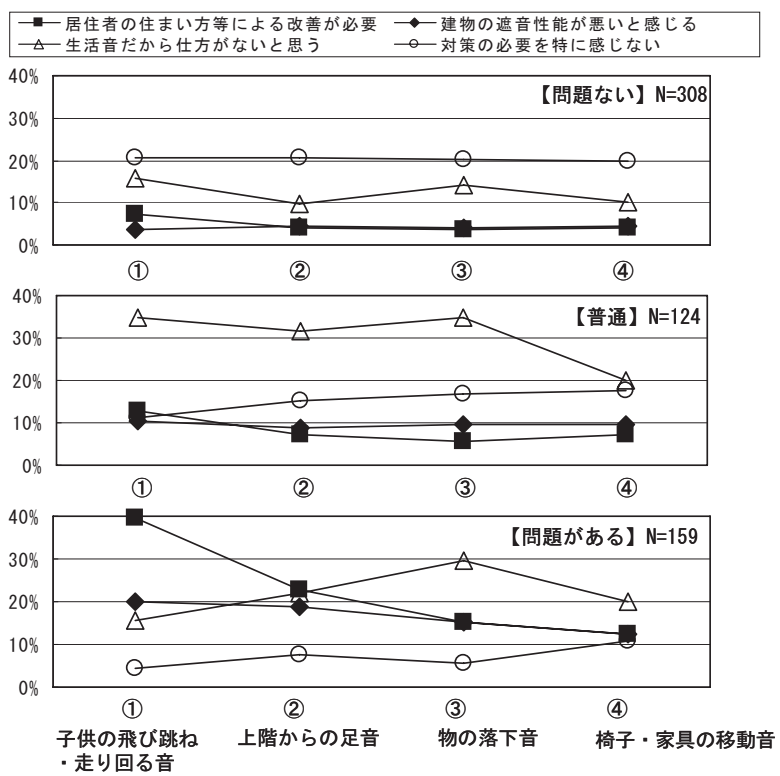

図 6 問題意識別の対策方法要求

居住後に発生する可能性がある 問題点なども説明された パンフレットに記載されている 内容などは説明された 特に説明されなかった

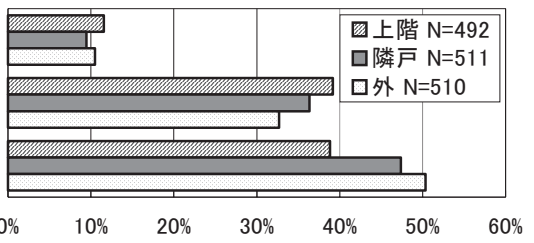

図 7 営業担当者等による購入前の事前説明の程度

表 4 具体的に説明された内容 (抜粋)

小さな子供が走り回ったり、物を落としたりする音が多少響くこともあるかもしれないがほとんど 気にならない程度だと思う。会話など聞こえることはありません。

マンションであれば絶対に聞こえないということはない。マンションとしては出来る限りの防音はし ている。

LL45でほとんど生活音は気にならない程度

上の音は聞こえません。問題ありません。

"音は気になならな”といわれたが、やはり大変気になる。

線路に近いことから馶音についての確認。＼cjkstart公を聞めると遮音性は高いと模刑を使って説明。

$\rightarrow$ 実際はかなり音が入る。

辟の厚さが $40 \mathrm{~mm}$ あるので、隣の音はまず聞こえない。衝撃を吸収するつくりになっているので 上から響く事はない

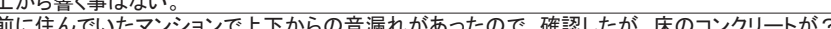

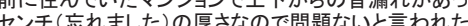

イスなど騒音が響くことが無い様、二重構造になっている。

䂞など騒音が響くことが無い様、

床下の高さがあるので防音がよい
音を吸収する床の作りになっています

表 5 購入前に説明して欲しかった内容 (抜粋)

2重床は、タイコのように、かえって音が響くこともあると説明された。隣家の子供の走り回る音は 集合住宅なので、ある程度は、仕方ないと思っておりました。説明は、十分していただけましたの

で、(それ以前に、認識済)不満ありません。

細かく説明してほいかった パンフレットのみでした。デメリットの説明がほとんどなかった。

子供が走ったり、大人が歩く音でも聞こえるという説明

子供が走ったり、大人が歩く音でも聑こえるという説明
どの様な音が伝わりやすい程度の音が聞こえる可能性があるか。

このアンケートにもある様な項目で具体的に説明がほしかった。

車の通過する音と停止から発進するときの音の程度の違いを具体的に数值 $(\mathrm{dB})$ で

実際に居住した際に、受け入れざるを得ない音の種類と大きさのレベルの具体的な例。

タワーマンションは遠方の音もよく聞こえるという説明は欲しかった。

風の強い日は、ベランダの壁を通過する高音がピューピューものすごくうるさい。

この場所で起こりうる問題点を提起して欲しかった。

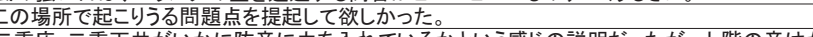
二重床·二重天井がいかに防音にカを入れているかという感
なり聞こえるので、その辺の所は表現を控えるべきだと思う。 床がクッション性があるので音の心配はあまりないときいていたので直上階の足音には頭にくる 上下階への音は全くしませんと言われ、何回も確認したが、結局、歩く音ですら聞こえる。はっき り言ってだまされた感じ。

実物大の模型をつくって、上階で音を発生させて体感する。

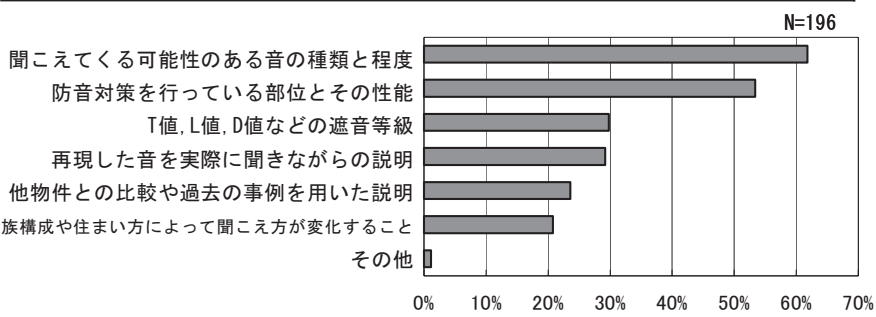

図 8 営業担当者が最低限説明すべき内容 
しかし、『重量床衝撃音』と『軽量床衝撃音』については、説明 の程度による大きな変化はみられない。この傾向は、問題意識の程 度を質問した結果でも示されており、既報10)11)でも報告したように 床衝撃音について供給者から適切に説明がなされていない可能性が あることから、居住後のトラブル防止への寄与のためにも、今後、 説明方法や内容の改善が必要であると考えられる。

一方、音環境は実際に住んでみないとわからない部分があること についてどう思うか」という質問に対する結果は、図 10 に示寸通 り、6 割の人が「仕方がないと思う」としながらも、3 割の人が「仕方 がないとは思えない」と回答している。しかし、「住宅購入にあたっ て音環境について自ら勉強したか」質問した結果（図 11 ) をみると、 「勉強していない」が半数、「勉強していないが、理解している」が 3 割となっている。既報10) で報告している、マンションのモデルルー ムを訪れた住宅購入予定者に事前勉強の有無を質問した結果でも、 約半数の人が勉強しておらず、購入する側の心構えにも改善の余地 があるといえる。

\section{4 住まい方}

\section{4.1 住まい方全般}

一般的な意見として、「集合住宅では他住戸の音環境を良好に保つ ために住まい方に配慮する必要があると思うか」の質問に対する結 果を図 12 に示す。「充分配慮する必要がある」が $58 \%$ 、「少し配慮する 必要がある」とあわせると 9 割以上の人が配慮の必要性を感じてい る。さらに、「他住戸の音環境を良好に保つために、自身の住まい方 が制限されることに対してどう思うか」の結果（図13) では、住まい 方が制限されることは「当然である」が $26 \%$ 、「仕方がない」とする回 答が $67 \%$ 、゙わせると 9 割以上の居住者が自身の住まい方が制限 されることを受け入れている。しかし、「当然である」との回答に対 して、「仕方がない」と回答している人が倍以上いることから、積極 的に住まい方が制限されることを受け入れているわけではなく、現 在の建築性能を感覚的に理解し、お互い様であるという意識からの 回答とも考えられることから、今後は、居住者が「仕方がない」では なく、「当然である」と回答できる程度まで建築性能の向上および居 住者の意識改善を図っていく必要があるのではないだろうか。

実際に、自分の出す音に配慮しているか質問した結果 (図 14 ) を みても、8 割の人が配慮していると回答しており、集合住宅に居住 する際、他住戸の音環境を良好に保つために自分の出す音に配慮す ることは「マナー」として受け入れられる可能性が高いといえる。今 後は、その程度を具体的に表す必要がある。

また、騒音トラブル防止のために必要だと思うものを回答しても らった結果(図 15) をみると、7 割以上の人が「個人のモラル・マナー の向上」および「防音性能など建築技術の向上」を指摘しており、技 術向上だけでなく居住者自身のモラル・マナーが同程度に重視され ているといえる。具体的に配慮している内容について質問した結果 を図 16 に示す。「必要があると思い、実際に配慮している」音源・項 目として、『楽器の使用時間帯』、『テレビ・ステレオの音量』、『掃 除機の使用時間帯』が 5 割を超えており、音を発生させる楽器や電 化製品の使用時間帯に注意することは集合住宅における標準的な住 まい方と意識されつつあると考えられる。しかし、必要あると思う が、配慮していない（実際には難しい）」音源として、『物の落下』、

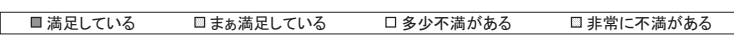

(1) 居住後に発生する可能性がある問題点なども説明された

(2) パンフレットに記載されている内容などは説明された

(3) 特に説明されなかった
【重量床衝撃音】

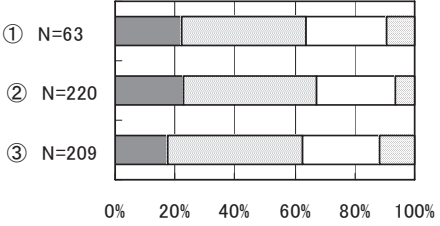

【隣戸からの音】

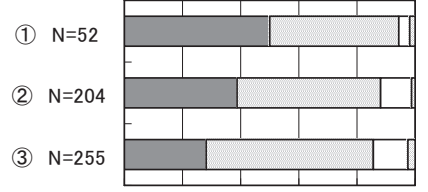

$\begin{array}{llllll}0 \% & 20 \% & 40 \% & 60 \% & 80 \% & 100 \%\end{array}$

図 9 事前説明の程度別の居住後の満足度

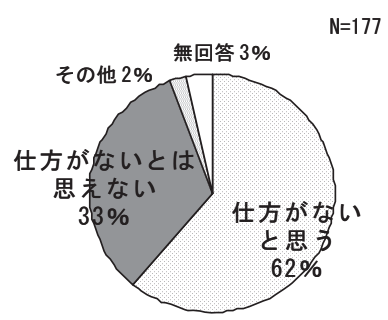

図 10 住んでみないと音環境 がわからないことについて

\section{【軽量床衝撃音】}

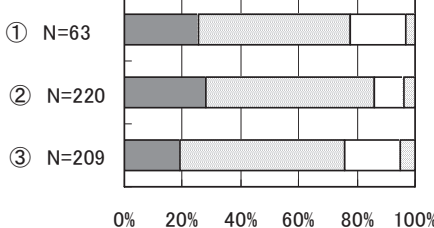

【外からの音】

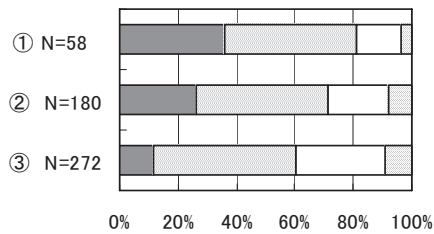

$\begin{array}{llllll}0 \% & 20 \% & 40 \% & 60 \% & 80 \% & 100 \%\end{array}$

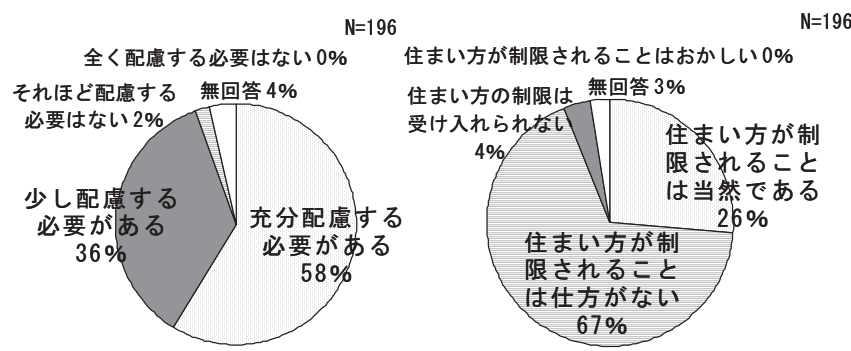

図 12 他住戸の音環境を良好 に保つために住まい方に配 慮する必要があるか

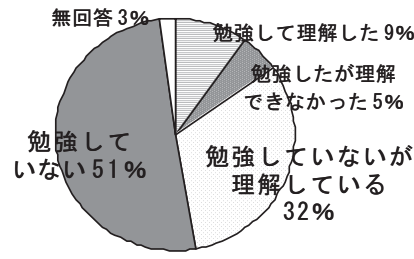

図 11 購入前に音環境に ついて勉強したか

図 13 他住戸の音環境を良好 に保つために、自身の住まい 方が制限されることに対して

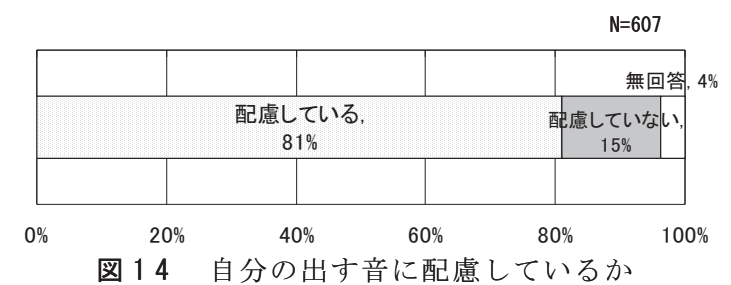

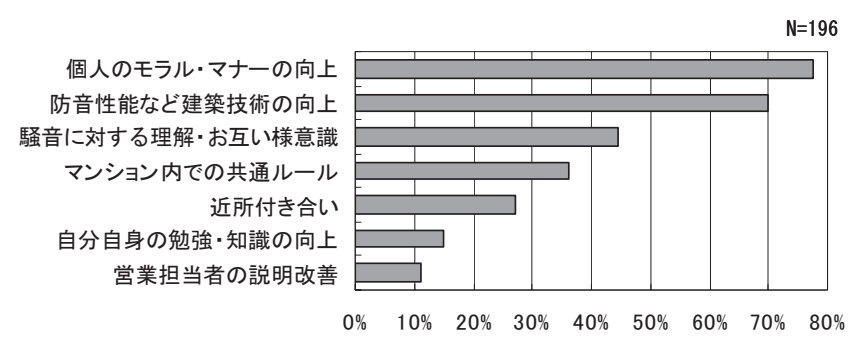

図 15 騒音トラブル防止のために何が必要か 
『歩き方・歩行』、『玄関扉・空・サッシ・襖・室内ドア等』などが あげられており、日常生活においてどうしても発生してしまうこれ らの音については、図 5 で聞こえる音・気になる音としても指摘さ れてることから、建築技術によって気にならない程度まで低減させ るべきであるといえる。すなわち、建築技術が達成すべき性能の決 定やランクの設定などはこのような結果を重視すべきであろう。

\section{4.2 子供の住まい方}

「子供の飛び跳ね・走り回る音」は、図 5 で聞こえる音・気になる 音として最も指摘が高く、図 6 で住まい方等による改善要求が出さ れているが、集合住宅に居住する際によ゙の程度までを㷣として行う べきなのか、価值観の違いによるトラブルも発生してきていること から、本項では子供の住まい方について検討した。

子供の立ち入りに対する抵抗感について質問した結果を図 17 に 示す。「自分の住むマンション内に子供が立ち入る」ことに抵抗があ る人は 2 割程度で、実際に「上階に子供が住む」ことに抵抗を持って いる人は $25 \%$ を超えている。これは、過去の居住経験などから子供 が騒音源となりうることを認知している場合、子供が近隣に住むメ リットを感じられないためと考えられ、静かな環境で暮らしたいと いう要求の表れと考えられる。

子供の住まい方に対する配慮への要求を質問した結果 (図 18 ) を みると、「共用部分では子供は静かにすべきだと思う」が 8 割程度で、 「上階に住む子供には住まい方に配慮して欲しい」が 7 割程度となっ ており、配慮して欲しい要求が高いことがわかる。

次に、子供が発生させる音について、「子供にはなるべく音を立て させないようにさせる必要があると思うか」の質問に対して、子供 の年齢別に小学生以下 (12 歳以下) と中学生以上でまとめた結果を 図 19 に示す。12 歳以下の子供がいる家庭では 9 割以上、12 歳以下 の子供がいない家庭でも 8 割の居住者が「はい」と回答しており、子 供の発生させる音は集合住宅においては大きいという共通認識があ り、居住者自身による対策の必要性を感じているといえる。

子供が発生させる音に対して何歳まで仕方がないと思うか質問し た結果を図 20 に示す。6 歳までとする人が累積で $50 \%$ を超えており、 就学前までは仕方がないと判断する傾向が強いようである。なお、 10 歳までとする人も比較的多いことから小学校低学年までと判断 する人もおり留意する必要がある。

実際に子供がいる家庭に対して、子供の走り回りに関して質問し た結果を子供の年齢別に集計し、傾向に違いがみられた 3 歳以下と 4 歳以上でまとめた結果を図 21 に示す。子供が「走り回らないよう にする必要があるか」質問した結果では、子供の年齢に関係なく8 割以上が必要性を感じているが、実際に配慮しているか質問した結 果では、1 歳から 3 歳の子供がいる家庭では、4 歳以上の子供がい る家庭に比べて「配慮していない(実際には難しい)」の割合が高い。 「子供の飛び跳ね」について質問した結果でも同様の傾向が示されて おり、子供の年齢により配慮の度合いに違いがみられる。B en e s s e の教育研究開発センターの報告 ${ }^{15)}$ によると、4 歳になるとある程度 自己規制ができるようになり我慢もできるようになるが、3 歳以下 では難しいという報告もあり、今回の調查結果と対応している。

図 21 からは 3 歳がひとつの目安と考えられるが、図 20 では 6 歳 が 1 つの目安として示されている。これは、幼稚園・保育園のよう な集団生活の中で人とのかかわりを学びながら発達が促されること
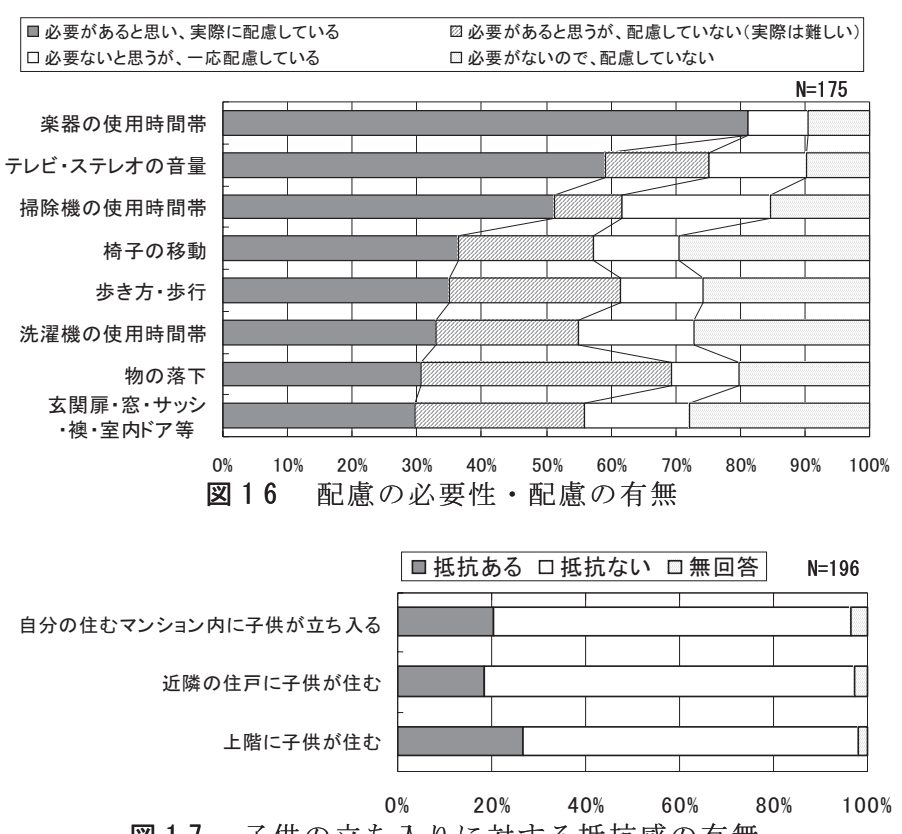

図 17 子供の立ち入りに対する抵抗感の有無

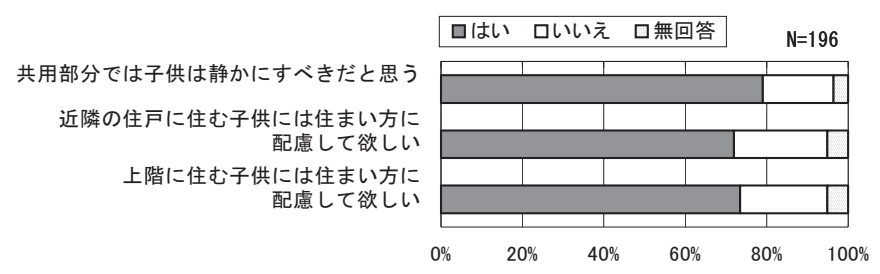

図 18 子供の住まい方に対する配慮への要求

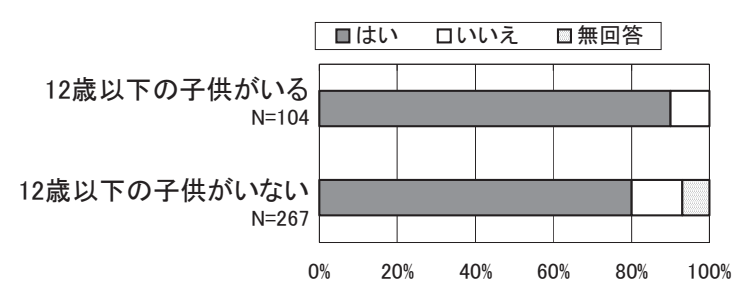

図 19 子供にはなるべく音を立てさせないように する必要があると思うか

$\mathrm{N}=163$

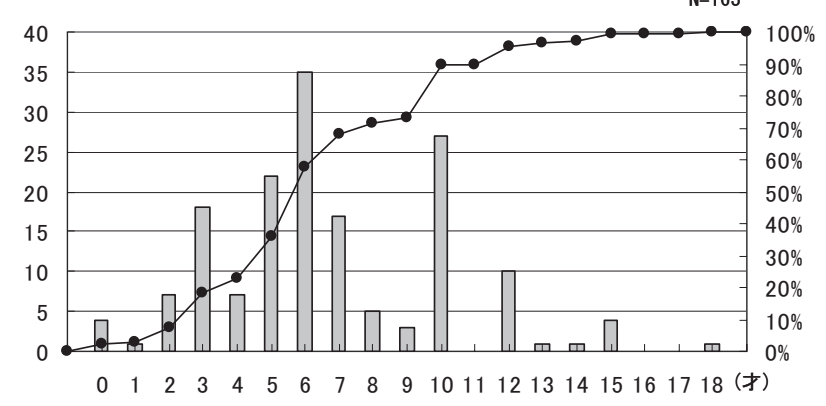

図 20 子供が発生させる音に対して何歳まで 仕方がないと思うか
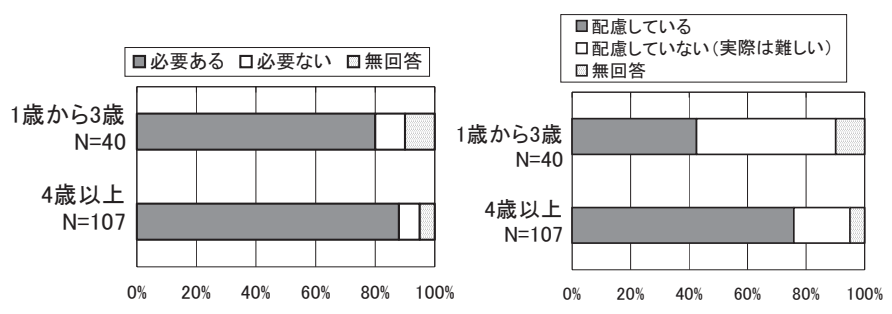

【走り回らないようにする必要があるか】

【配慮しているか】

図 21 子供の走り回り：配慮の必要性と配慮の有無 
や、子供によってそれぞれ発達に個人差があることなどを踏まえた うえで、図 20 では 6 歳が 1 つの目安として考えられていると思われ る。

これらを総合すると、子供の発達過程からみても未就園児である 3 歳までの子供に対して「走り回らない」、飛び跳ねない又はその程 度を表す住まい方を提案することは難しいと考えられることから、 3 歳までの子供に対しては周りの理解が必要であると共に、まずは 3 歳までの子供が発生させる床衝撃音 (加振力) に対する建築的対策 を空間的性能と併せて考えて行く必要があるといえる。なお、本論 文では 3 歳を 1 つの目安として捉えたが、今後、何歳の子供の床衝 撃音 (加振力) を軸として用いることが望ましいのか、子供の年齢別 に、住まい方により下階音圧レベルをどの程度改善できるのか、そ の効果量を明らかにしていくことで、建築技術と住まい方とのバラ ンスをどう保つべきなのか検討していく必要がある。また、併せて 具体的に効果がある住まい方を導入・周知していくことで、子供に よる騷音トラブルを低減させていくことができるのではないだろう か。

\section{4. まとめ}

近年 (竣工が 2000 年以降) の集合住宅選定時の建築性能に対する 考慮の度合いは非常に高く、高い空間性能を要求している様子が伺 える。一方、居住後の満足度も全体的に高いことから、考慮度合い の高い消費者要求を近年の集合住宅では、ほぼ満足させていること が示された。しかし、不満が 1 番高い項目として音環境があげられ ている。特に「重量床衝撃音」と「空気伝搬音(外壁開口部)」に対する 不満がみられ、これらの音に対しては居住者要求を満たすまでには 至っていない。

聞こえる音・気になる音として、「給排水音」は近年の住宅では大 きく改善されているものの、「子供の飛び跳ね・走り回る音」等の床 衝撃音の指摘が依然として高く、改善の難しさが浮き彫りとなっ た。具体的な改善策として、「子供の飛び跳ね・走り回る音」につい ては、居住者の住まい方等による改善要求も高く、生活実感を向上 させるためには、住まい方の改善も重要な要因の 1 つであると認識 されつつあることが示された。

購入前の営業担当者等の音環境性能に関する事前説明内容は、建 築仕様のみの説明や曖昧な説明が多く、既報 10)11) で示した供給者の 実態が居住者反応からも改めて示された。また、消費者からはより 具体的な説明要求が示されたことから、今後、消費者要求を反映し た供給者の説明方法・内容の改善が求められる。一方、消費者の約 半数が音環境に関する事前の勉強をしておらず、購入する側にも今 後の課題がみられる。

集合住宅に居住する際に住まい方に制限を受けることは、程度の 問題は残るが居住者反応より「マナー」として受け入れられる可能性 が高いといえる。なお、楽器や電化製品の使用時間帯に注意するこ とは、集合住宅に住まう際のマナーとして認知されつつあるようで ある。しかし、『物の落下』、『歩き方』、『玄関扉・空・サッシ・襖・ 室内ドア等の開閉方法』については、配慮の必要性を感じていなが ら実際には難しいと感じている事が示されたことから、住まい方の 工夫や周知の方法と共に技術的対処を併せて考えて行くべきであ る。
さらに、上階に子供が住むことに抵抗がある人は 4 人に 1 人で、 8 割以上の人が子供になるべく音を立てさせないようにさせる必要 性を感じており、子供をめぐる騒音問題が深刻に受け止められてい るようである。子供が発生させる音については、6 歳までは仕方が ないとする人が半数を超えているが、実際に子供のいる家庭では、 3 歳以下の子供に対して「走り回り」や「飛び跳ね」について配慮の必 要性を感じていながらも、実際に配慮する事が難しい結果が示され たことから、子供の住まい方と建築技術のバランスについて検討し ていく必要がある。

今後は、目標とする遮音性能の技術レベルをより具体的に示して いくと共に、消費者要求を反映させた説明が販売時に行なえるよう に、床衝撃音遮断性能別や子供が居住した場合の生活実感の反応変 化についても提案していく予定である。また、ソフト面による生活 実感改善の可能性について、住まい方とその効果についても検討を 行なっていく予定である。

\section{謝辞}

調査の実施・分析にご協力頂いた、日本大学井上研究室平成 19 年度修士論文生の大室諒知君、平成 15 年度〜平成 19 年度に本テー マについて卒業論文で取り組んだ性能表示班の諸君、並びに、各物 件の管理組合や居住者の方々に心より厚く御礼申しあげ、ここの感 謝の意を表します。

\section{参考文献}

1）国土交通省住宅局総合整備課マンション管理対策室：平成 15 年度マン ション総合調査結果

2）内閣府「社会意識に関する世論調查」から厚生労働省政策統括官付政策評価 官室にて作成：近所付き合いの程度の変遷

3）国土交通省住宅局住宅政策課：平成 15 年住宅需要実態調査結果

4）光田泰子、木村翔：集合住宅における生活騒音の実態と T N E L による 評価：日本建築学会論文報告集、第 272 号、1978.10

5）光田泰子、木村翔：集合住宅における床衝撃音の評価に関する研究：日 本建築学会環境工学論文集、1981.5

6）木村翔、井上勝夫、荘美知子、藤沢一弘：集合住宅の音環境に対する居 住者意識と住まい方に関する研究 : 日本建築学会計画系論文集、第 466 号、 pp. $1 \sim 8 、 1994.12$

7）荘美知子、木村翔、梶裕佳子、鈴木久恵 : 集合住宅の音環境に対する居 住者意識の形成に関する研究一自由意見の分析を通してー：日本建築学 会計画系論文集、第 485 号、pp. $1 \sim 8 、 1996.7$

8）荘美知子、木村翔、鈴木久恵、梶裕佳子：集合住宅の住環境全般と音環 境に対する居住者評価の分析：日本建築学会計画系論文集、第 493 号、pp. 9 $\sim 15 、 1997.3$

9）荘美知子、木村翔、梶裕佳子：集合住宅の音環境に対する居住者意識構 造の分析 : 日本建築学会計画系論文集、第 506 号、pp. $1 \sim 7 、 1998.4$

10) 阿部今日子、井上勝夫 : 音環境に関する集合住宅購入時の消費者要求と 住宅供給者の説明：日本建築学会環境系論文集、第. 595 号、pp. $9 \sim 16$ 、 2005. 9

11) 阿部今日子、井上勝夫 : 住宅性能表示制度と集合住宅の音環境に関する 居住者・供給者の意識調査 : 日本建築学会技術報告集、第 27 号、pp. 173 $-178 、 2008.6$

12) 阿部今日子、井上勝夫、大室諒知：集合住宅の音環境性能に対する説明要 求住宅購入時の消費者要求と住宅性能表示制度その 8 : 日本建築学会大会 講演講演梗概集、D-1 分冊、pp. $125-126 、 2006.9$

13) 大室諒知、井上勝夫、阿部今日子：集合住宅の音環境性能に対する住まい 方の効果 住宅購入時の消費者要求と住宅性能表示制度その 9 : 日本建築 学会大会講演講演梗概集、D-1 分冊、pp. $127-128 、 2006.9$

14) 国土交通省 : 建築着工統計調查

15) B enesse 教育研究開発センター : 第 3 回幼児の生活アンケート報告書

16）日本建築学会編：建築物の遮音性能基準と設計指針（第二版）、技報堂出 版、1997. 12 